\title{
Age related prevalence of hepatitis $G$ virus in South Africans
}

\author{
M Jeffrey Mphahlele, Sanet Aspinall, Richard Spooner, William F Carman
}

\begin{abstract}
Aim-To investigate the age related prevalence of hepatitis G virus (HGV) infection and its mode of transmission in relation to hepatitis $B$ (HBV) and C (HCV) coinfection in South African blacks. Methods-Reverse transcriptase polymerase chain reaction was performed to detect active infection, using primers for the 5'-NCR, NS5a, and NS3 regions. Antibodies to HGV envelope-2 protein (antiE2), which measures past infection, were also sought.

Results-The overall prevalence of active infection was $116 / 580(20 \%)$. A higher prevalence was noted in HBsAg carriers (28/106; 26.4\%) and HCV positive subjects $(25 / 82 ; 30.5 \%)$. In contrast to developed countries, active and past infection was seen in $12.9 \%$ and $12.1 \%$ of the general population, respectively (subjects negative for HBsAg and anti-HCV markers and with normal alanine aminotransferase values), with a total prevalence of $21.1 \%$ (52/248). Viraemia and anti-E2 were almost mutually exclusive. The distribution of viraemia by age was: $\leqslant 15$ years, $20 / 223$ $(9.0 \%) ; 16-35$ years, $42 / 147(28.6 \%) ; \geqslant 36$ years, $37 / 151(24.5 \%)$, with a significant difference $(p=0.001)$ in age related prevalence. A similar trend was observed for the prevalence of past infection in the general population.
\end{abstract}

Conclusions-HGV infection begins in childhood and increases with age in South Africa, but transmission is largely independent of HBV and HCV. No association was found between HGV viraemia and hepatitis, or with co-infection with either HBV or HCV.

(F Clin Pathol 1999;52:752-757)

Department of

University of Southern

Africa, Pretoria, South

Africa

M J Mphahlele

S Aspinall

Institute of Virology, University of Glasgow, Church Street, Glasgow G11 5JR, UK W F Carman

Department of

Biochemistry,

University of Glasgow

R Spooner

Correspondence to:

Dr Carman.

Accepted for publication 4 June 1999

Keywords: hepatitis G; hepatitis B; hepatitis C; prevalence; transmission

Hepatitis G virus (HGV) and GBV-C (both subsequently referred to as $\mathrm{HGV}$ in this paper) were independently identified from a case of chronic hepatitis. ${ }^{12} \mathrm{HGV}$ is a positive sense RNA virus of the family Flaviviridae. It is related to, but quite distinct from, hepatitis $\mathrm{C}$ virus (HCV) as it shares only $25 \%$ amino acid sequence homology. ${ }^{23}$

The global epidemiology and risk factors for acquisition of $\mathrm{HGV}$ infection are currently unclear. Data generated from developed, nonAfrican countries indicate that HGV is transmitted parenterally. High prevalence was noted in intravenous drug users, ${ }^{245}$ haemodialysis patients, ${ }^{6}$ and people with haemophilia. ${ }^{2} \mathrm{Be}-$ tween $1 \%$ and $4 \%$ of blood donors in developed countries are $\mathrm{HGV}$ viraemic. ${ }^{24-6}$ Mother to infant transmission is common ${ }^{78}$ and appears to be dependent upon maternal viraemia. $^{9}$ Detection of HGV RNA in semen ${ }^{10}$ and saliva ${ }^{11}$ has also raised the possibility of transmission by other body fluids. It has been suggested that outdoor exposure from arthropods can lead to a high prevalence in individuals without other risk factors. ${ }^{12}$

Although HGV was originally identified in hepatitis patients, ${ }^{12}$ the link to hepatitis has become less certain. There are very few data showing that HGV can independently cause hepatitis, as most cases with hepatitis are also infected with either $\mathrm{HBV}$ or $\mathrm{HCV}$ (or both). ${ }^{2413}$ Furthermore, less than $16 \%$ of nonA-E hepatitis cases are also HGV viraemic (see Mphahlele et al for review $\left.{ }^{14}\right)$. However, the recent detection of $\mathrm{HGV}$ antigenomic RNA in the liver suggests that HGV is hepatotropic, ${ }^{15} 16$ although this possibility is diluted by other reports that do not support the liver as the primary replication site of $\mathrm{HGV} .^{17}$

While most studies have been conducted in developed countries, little is known about the epidemiology of $\mathrm{HGV}$ in Africa. Based on limited studies, it appears that there is a high prevalence of HGV infection in subSaharan Africa. One study has reported HGV viraemia of $14.2 \%$ of a random population in West Africa where HBV infection is extremely common. ${ }^{4}$ In South Africa, two recent independent studies have confirmed a high prevalence $(10-12 \%)$ of $\mathrm{HGV}$ in the general population..$^{18}$

Here we report on the age related prevalence of HGV infection from rural and urban populations in South African blacks, and further show that transmission of HGV is largely independent of $\mathrm{HBV}$ and $\mathrm{HCV}$ co-infection in this region.
Methods

STUDY POPULATION GROUPS

A total of 580 stored $\left(-20^{\circ} \mathrm{C}\right)$ serum samples collected from South African blacks formed the basis of this study (table 1). The samples were collected from three different areas in South Africa: the Ga-Rankuwa and Soshanguve area (urban townships near Pretoria), Gauteng, and a rural village in Venda, Northern Province (north of Gauteng).

SEROLOGY

The following assays were used: IgG and $\operatorname{IgM}$ anti-HAV (Abbott Laboratories); HBsAg, anti$\mathrm{HBc}$, anti-HBs (IMx, Abbott Laboratories); anti-HCV (anti-HCV version III, Murex 
Table 1 Study groups tested for hepatitis $G$ virus (HGV) RNA and/or anti-E2 antibodies

\begin{tabular}{lllll}
\hline Clinical group & Age range & Mean age & $n$ & Region \\
\hline General population & & & 248 & \\
$\quad$ Group I (n=104) & $0-4$ months & 3.6 months & & Soshanguve, urban \\
Group II (n=56) & $1-15$ years & 8.3 years & & Venda, rural \\
$\quad$ Group III (n=88) & $1-94$ years & 28 years & & Ga-Rankuwa, urban \\
Hbst carriers & $3-76$ years & 31 years & 106 & Ga-Rankuwa hospital \\
Anti-HCV and/or HCV RNA positive & $5-80$ years & 42.8 years & 82 & Ga-Rankuwa hospital \\
Non-current A-E, no past HBV† & $4-71$ years & 38.2 years & 76 & Ga-Rankuwa hospital \\
Non-current A-E, past HBV & $2-65$ years & 28.3 years & 68 & Ga-Rankuwa hospital \\
Total & & & $\mathbf{5 8 0}$ & \\
\hline
\end{tabular}

^HBsAg negative and anti-HCV negative; no tests were done for HAV, HDV, or HEV.

†HAV IgM negative, HBV all markers including IgM anti-HBc negative, anti-HCV negative and IgM anti-HEV negative.

$\ddagger$ Same as $\dagger$, but anti-HBs and anti-HBc postive, indicating past exposure to HBV.

Diagnostics); anti-HEV (total and IgM), analysed by HEV enzyme immunoassay (EIA) (Abbott Laboratories). For anti-HCV, samples were confirmed with HCV EIA supplemental assay (Abbott Laboratories). Antibodies to HGV envelope-2 protein (anti-E2) were performed with $\mu$ plate anti-HGenv (Roche Diagnostics).

RNA EXTRACTION

Total RNA was extracted from $140 \mu \mathrm{l}$ serum using the QIAamp HCV RNA kit (Qiagen) according to the manufacturer's instructions.

CDNA SYNTHESIS

Ten microlitres of extracted RNA were reverse transcribed in a total of $20 \mu \mathrm{l}$ reaction mix (200 $\mathrm{mM}$ dNTP mix (Gibco BRL); $2 \mathrm{mM}$ random hexamers (Promega); 1 U RNase inhibitor (Promega), $10 \mathrm{mM}$ dithiothreitol (DTT), pH 8.5 (Roche Diagnostics); and $20 \mathrm{U}$ M-MLV reverse transcriptase (Roche Diagnostics)). Annealing of primers to RNA was conducted at $25^{\circ} \mathrm{C}$ for 10 minutes, followed by reverse transcription at $37^{\circ} \mathrm{C}$ for 55 minutes, and denaturation of products at $95^{\circ} \mathrm{C}$ for five minutes.

POLYMERASE CHAIN REACTION ASSAYS

Two independent polymerase chain reaction (PCR) protocols were used to detect $\mathrm{HGV}$ RNA: the Roche HGV PCR primer probe assay, ${ }^{5}$ and an in-house PCR with degenerate primers directed to the conserved NS3 helicase region..$^{2021}$

Roche HGV PCR primer probe assay

This was performed using two independent sets of primers for the $5^{\prime}-\mathrm{NCR}$ and NS5a regions essentially as described. ${ }^{5}$ For each sample, $5 \mu \mathrm{l}$ of reverse transcription mix were PCR amplified in duplicate, each with a different pair of primers, in a total of $50 \mu$ reaction mix using the Expand high fidelity PCR system and digoxygenin (DIG) labelled dNTPs. One single round of 45 cycles each of denaturation at $94^{\circ} \mathrm{C}$ for 30 seconds, annealing at $55^{\circ} \mathrm{C}$ for 40 seconds, and extension at $70^{\circ} \mathrm{C}$ for $2.5 \mathrm{~min}$ utes was performed, with a final elongation at $70^{\circ} \mathrm{C}$ for seven minutes.

In-house PCR assay

In parallel, an in-house reverse transcriptase PCR (RT-PCR) for the detection of HGV NS3 sequences was developed and its sensitivity was evaluated against the Roche PCR assay. The NS3 region was amplified by a touch-down PCR protocol in $0.2 \mathrm{ml}$ thin walled tubes as described, ${ }^{20}$ using degenerate, seminested primers. $^{2021}$

Evaluating the sensitivity of RT-PCR techniques

HGV controls (high positive, low positive, and negative control) from Roche Diagnostics were used to compare the sensitivity of both PCR assays. The supplied low and high positive controls were diluted to end point in a negative serum. The highest positive dilution, as well as the negative serum, were included in every PCR experiment. In addition, negative controls containing only PBS were included after every fourth sample during RNA extraction, cDNA synthesis, and PCR amplifications of clinical samples.

DETECTION OF PCR AMPLIFICATION PRODUCTS Roche PCR assay

Roche PCR enzyme linked immunosorbent assay (ELISA) DIG detection kit was employed to detect DIG labelled PCR products. Ten microlitres of PCR products were denatured in $20 \mu \mathrm{l}$ of $50 \mathrm{mM} \mathrm{NaOH}$ for 10 minutes at $25^{\circ} \mathrm{C}$. The denatured mix $(30 \mu \mathrm{l})$ was added to $200 \mu \mathrm{l}$ hybridisation solution (phosphate buffered saline (PBS), pH 6.5) containing 75 $\mathrm{ng} / \mathrm{ml}$ of biotin labelled capture probe. The mix was added onto microtitre plate wells coated with streptavidin. After 1.5 hours' incubation at $37^{\circ} \mathrm{C}$ on a shaker, the plate was washed four times with PBS, and $200 \mu \mathrm{l}$ of anti-DIG peroxidase was added. Incubation was allowed at $37^{\circ} \mathrm{C}$ for 30 minutes on a shaker. The plate was washed as above and $200 \mu \mathrm{l}$ of peroxidase substrate plus $1.9 \mathrm{mM} 2,2^{\prime}$ azino di[3ethylbenzthiazoline sulphonate] was added. The plate was incubated in the dark at $37^{\circ} \mathrm{C}$ for 30 minutes for colour development. The results were interpreted both visually and at $405 \mathrm{~nm}$ in an ELISA reader for semiquantitative analysis. A sample was scored positive if it was detected by both $5^{\prime}-\mathrm{NCR}$ and NS5a primer pairs or if the sample OD was more than three times the negative control optical density (OD). If only one set of primers was reactive, then the sample was either repeated or retested using an in-house PCR.

In-house PCR assay

For the detection of NS3 amplification products, $5 \mu \mathrm{l}$ of the second round PCR products were run on $2 \%$ ethidium bromide stained agarose gels, and a band of 140 base pairs (bp) was visualised under ultraviolet light transillumination.

SEQUENCING OF THE HGV NS3 PCR PRODUCTS

The rationale for sequencing was twofold: first, to confirm that the bands were HGV specific; second, to partially assess the degree of nucleotide sequence variability in the NS3 region of South African field isolates, particularly at the primer binding sites of the primers used for our in-house RT-PCR. Seven samples which reacted with both the 5'-NCR and NS5a primers were selected at random for sequencing. 
Table 2 Differential sensitivity of 5'-NCR, NS5a, and NS3 primers for detection of HGV RNA on South African samples

\begin{tabular}{llllll}
\hline & & \multicolumn{2}{l}{ Roche PCR primer probe assay } & In-house RT-PCR assayt \\
\cline { 3 - 5 } Roche PCR primers & $\begin{array}{l}\text { Selected groups } \\
(n=332)\end{array}$ & $\begin{array}{l}\text { Ga-Rankuwa urban } \\
\text { population }(n=88)\end{array}$ & $\begin{array}{l}\text { Soshanguve urban } \\
\text { neonates }(n=104)\end{array}$ & $\begin{array}{l}\text { Venda rural children } \\
(n=56)\end{array}$ & $\begin{array}{l}\text { Total HGV RNA } \\
\text { positivity }(n=580)\end{array}$ \\
\hline 5'-NCR only & $22(6.6 \%)$ & $5(5.7 \%)$ & $3(2.9 \%)$ & $0(0)$ & $30(5.2 \%)$ \\
NS5a only & $35(10.5 \%)$ & $8(9.1 \%)$ & $0(0)$ & $7(12.5 \%)$ & $50(8.6 \%)$ \\
Both & $27(8.1 \%)$ & $8(9.1 \%)$ & $0(0)$ & $1(1.8 \%)$ & $36(6.2 \%)$ \\
Total & $\mathbf{8 4}(\mathbf{2 5 . 3 \% )}$ & $\mathbf{2 1}(\mathbf{2 3 . 9 \% )}$ & $\mathbf{3 ( 2 . 9 \% )}$ & $\mathbf{8 ( 1 4 . 3 \% )}$ & $\mathbf{1 1 6}(\mathbf{2 0 . 0 \% )}$ \\
\hline
\end{tabular}

*Include the following groups: HBsAg positives ( $\mathrm{n}=106)$; anti-HCV and/or HCV RNA positives (n=82); non-current A-E, no past HBV (n=76); non-current A-E, past HBV $(n=68)$.

†In-house RT-PCR was conducted on all samples which reacted with only 5'-NCR $(n=30)$ or NS5a $(n=50)$ primers and also on all samples ( $\mathrm{n}=36)$ which reacted with both $5^{\prime}$-NCR and NS5a primers.

RT-PCR was conducted essentially as described for the in-house RT-PCR above, ${ }^{20}$ except that different sets of primers were employed. ${ }^{22}$ The primer sequences were reported previously ${ }^{22}$ and are ideal to generate longer PCR fragments that allow sequencing across the primer binding sites of the primers used for our in-house RT-PCR. After electrophoresis, a $300 \mathrm{bp}$ specific product of the second round PCR mix was excised, gene cleaned (Bio 101), and sequenced (USB, Amersham Life Sciences). Sequencing was conducted with both the sense and antisense primers for each sample.

\section{Results}

DIFFERENTIAL SENSITIVITY OF 5'-NCR, NS5a, AND NS3 PRIMERS FOR DETECTION OF HGV RNA

The sensitivity and specificity of the Roche PCR assay have previously been established. ${ }^{5}$ We found this assay to be slightly more sensitive (at least 100-fold) than our in-house RT-PCR using serial dilutions of HGV low and high positive controls (data not shown). All the clinical samples were first screened for HGV RNA with the Roche PCR assay; our in-house PCR, which employed seminested primers to the NS3 region, was then used to resolve any discrepancy between the Roche PCR primer pairs.

In total, 116 of 580 samples $(20.0 \%)$ tested HGV RNA positive with Roche PCR assay: 36 $(6.2 \%)$ with both 5 '-NCR and NS5a primer pairs, $30(5.2 \%)$ with the 5 '-NCR primers, and $50(8.6 \%)$ with the NS5a primers (table 2). Thus 80 samples which reacted with either the 5'-NCR or the NS5a primers (but not both) were further subjected to our in-house PCR to validate their positivity for $\mathrm{HGV}$ RNA. Of these, only 13 Roche PCR positive samples could not be detected with our in-house PCR. However, these 13 samples yielded consistently positive results after two extractions with the Roche PCR assay.
DISTRIBUTION OF HGV VIRAEMIA IN DIFFERENT STUDY GROUPS

Active HGV infection was found in $26.4 \%$ of the HBsAg carriers (28 of 106), 30.5\% of the anti-HCV and/or HCV RNA positive individuals (25 of 82 ), $21.1 \%$ of the non-current A-E, no past HBV group (16 of 76), $22.1 \%$ of the non-current A-E, past HBV group (15 of 68 ), and $12.9 \%$ of the general population $(32 / 248)$ (table 3). HGV RNA positivity in the latter group comprised three of 104 urban neonates $(2.9 \%)$ from Soshanguve, eight of 56 rural children from Venda (14.3\%), and 21 of 88 urban children and adult populations from Ga-Rankuwa (23.9\%) (table 2).

HGV DISTRIBUTION IN DIFFERENT AGE GROUPS

A lower prevalence (three of $104 ; 2.9 \%$ ) was seen in the neonates (less than four months of age), suggesting that vertical transmission of HGV is not common in South Africa (table 2). In contrast, eight of 56 rural children (less than 15 years of age) $(14.3 \%)$ were $\mathrm{HGV}$ viraemic (table 2). Of the eight $\mathrm{HGV}$ infected children, three were between one and two years of age, three between six and eight years, and two between 13 and 14 years. HGV viraemia in the general population of $\mathrm{Ga}$ Rankuwa was found to be $23.9 \%$ (21 of 88 ) (table 2). All but three of the $21 \mathrm{HGV}$ positive individuals were adults (more than 16 years old). Thus, for the general population, a higher prevalence was noted in the urban adult population of Ga-Rankuwa $(23.9 \%)$ than in the rural children from Venda $(14.3 \%)$ or neonates from Soshanguve (2.9\%). The overall distribution for all subjects by age was: $\leqslant 15$ years, $9.0 \%$ (20 of 223 ); $16-35$ years, $28.6 \%$ ( 42 of 147 ); $\geqslant 36$ years, $24.5 \%$ (37 of 151). There was a significant $(\mathrm{p}=0.001)$ age related difference in prevalence (table 3 ).

Table 3 Age related prevalence of HGV viraemia in South Africa

\begin{tabular}{|c|c|c|c|c|c|c|c|c|c|c|c|}
\hline \multirow[b]{3}{*}{ Group } & \multirow[b]{3}{*}{$N$} & \multicolumn{8}{|c|}{ Age groups (years) } & & \\
\hline & & \multicolumn{2}{|l|}{$\leqslant 15$} & \multicolumn{2}{|l|}{$16-35$} & \multicolumn{2}{|l|}{$\geqslant 36$} & \multicolumn{2}{|c|}{ Unknown } & \multicolumn{2}{|c|}{ Total positives/group } \\
\hline & & $n$ & $\%$ & $n$ & $\%$ & $n$ & $\%$ & $n$ & $\%$ & $n$ & $\%$ \\
\hline General population* & 248 & $14 / 185$ & 7.6 & $12 / 38$ & 37.5 & $3 / 18$ & 16.7 & $3 / 7$ & 42.9 & $32 / 248$ & 12.9 \\
\hline HbsAg carriers & 106 & $1 / 11$ & 9.1 & $16 / 50$ & 32.0 & 9/32 & 28.1 & $2 / 13$ & 15.4 & $28 / 106$ & 26.4 \\
\hline HCV positives & 82 & $0 / 4$ & 0 & $8 / 19$ & 42.0 & 9/35 & 25.7 & $8 / 24$ & 33.3 & $25 / 82$ & 30.5 \\
\hline Non-current A-E, no past HBV & 76 & $3 / 14$ & 21.4 & $3 / 23$ & 13.0 & $9 / 32$ & 28.1 & $1 / 7$ & 14.3 & $16 / 76$ & 21.1 \\
\hline Non-current A-E, past HBV & 68 & $2 / 9$ & 22.0 & $3 / 17$ & 17.6 & $7 / 34$ & 21.0 & $3 / 8$ & 37.5 & $15 / 68$ & 22.1 \\
\hline Total & 580 & $20 / 223$ & 9.0 & $42 / 147$ & 28.6 & $37 / 151$ & 24.5 & 17159 & 28.8 & $116 / 580$ & 20.0 \\
\hline
\end{tabular}

*Includes populations from Ga-Rankuwa $(\mathrm{n}=88)$, Venda $(\mathrm{n}=56)$, and Sosanguve $(\mathrm{n}=104)$. 
Table 4 Distribution of current and past HGV infection in the South African general population

\begin{tabular}{|c|c|c|c|c|c|c|c|c|c|}
\hline \multirow{2}{*}{$\begin{array}{l}\text { Age } \\
\text { (years) }\end{array}$} & \multirow[b]{2}{*}{ Tested } & \multicolumn{2}{|c|}{$\begin{array}{l}H G V R N A \\
\text { positive }\end{array}$} & \multicolumn{2}{|c|}{$\begin{array}{l}\text { Anti-E2 } \\
\text { positive }\end{array}$} & \multicolumn{2}{|c|}{$\begin{array}{l}\text { Both HGV RNA and } \\
\text { anti-E2 positive }\end{array}$} & \multicolumn{2}{|c|}{$\begin{array}{l}\text { Total } \\
\text { prevalence* }\end{array}$} \\
\hline & & $n$ & $\%$ & $n$ & $\%$ & $n$ & $\%$ & $n$ & $\%$ \\
\hline$\leqslant 10$ & 154 & 10 & 6.5 & 8 & 5.2 & 2 & 1.3 & 16 & 10.4 \\
\hline $11-15$ & 31 & 4 & 13.0 & 2 & 6.5 & 0 & 0.0 & 6 & 19.4 \\
\hline $16-25$ & 23 & 5 & 21.7 & 8 & 34.8 & 4 & 17.4 & 9 & 39.0 \\
\hline $26-35$ & 15 & 7 & 46.6 & 5 & 33.3 & 3 & 20.0 & 9 & 60.0 \\
\hline $36-45$ & 7 & 0 & 0.0 & 1 & 1.4 & 0 & 0.0 & 1 & 1.4 \\
\hline$>45$ & 11 & 3 & 27.3 & 4 & 36.4 & 0 & 0.0 & 7 & 63.6 \\
\hline Unknown & 7 & 3 & 42.9 & 2 & 28.6 & 1 & 14.3 & 4 & 57.1 \\
\hline Total & 248 & 32 & 12.9 & 30 & 12.1 & 10 & 4.0 & 52 & 21.1 \\
\hline
\end{tabular}

*Total prevalence is expressed as the sum of HGV RNA and anti-E2 positives (excluding samples positive for both markers).

ANTI-E2 DISTRIBUTION

This was studied in the general population only. Of the 248 samples, 30 (12.1\%) were anti-E2 positive, a similar prevalence to viraemia $(12.9 \%)$, bringing the total burden of HGV infection to $21 \%$ (table 4 ). As in other studies, ${ }^{23-25}$ these two markers were almost mutually exclusive, being present together in only $10(4.0 \%)$ of 248 samples.

HGV RNA AND ALANINE AMINOTRANSFERASE ESTIMATIONS

Alanine aminotransferase (ALT) estimations were studied in selected samples $(\mathrm{n}=302)$. Of those analysed, three of $79(3.8 \%)$ had raised ALT (> $50 \mathrm{U} / 1)$ and HGV RNA simultaneously, while 15 of $223(6.7 \%)$ had raised ALT without evidence of $\mathrm{HGV}$ viraemia. No correlation was found between $\mathrm{HGV}$ viraemia and raised ALT.

SEQUENCE ANALYSIS OF THE NS3 REGION OF SOUTH AFRICAN HGV STRAINS

A 214 bp PCR amplification fragment, corresponding to nucleotide 4285 to 4489 of the NS3 helicase region of $\mathrm{HGV}$ strain
PNF2161(U44402), was sequenced. The nucleotide sequences obtained from the South African strains were compared with those of the following prototype $\mathrm{HGV} / \mathrm{GBV}-\mathrm{C}$ strains (GenBank accession numbers in parentheses): PNF2161 (U44402), ${ }^{2}$ R10291 (U45966), ${ }^{2}$ GBV-C (West Africa) (U25538), ${ }^{1}$ and GBV-C (East Africa) (U63715). ${ }^{26}$

First, a high nucleotide sequence variability (81-91\% homology) was observed throughout the NS3 fragment between the South African HGV isolates (fig 1). This variation was less pronounced in the primer binding regions (for the primers used in our in-house RT-PCR assay); only a few nucleotide variations were observed (fig 1, bold case on primer sequences). The South African strains were found to be highly conserved (92-100\% identity) at amino acid level, but variable (81-91\% homology) at the nucleotide level. NS3 amino acid conservation is thought to reflect the biological significance of this protein.

Second, although the region sequenced was not large, the South African HGV strains compared very well with the prototype strains (83$88 \%$ nucleotide identity and $95-100 \%$ amino acid identity).

\section{Discussion}

Active $\mathrm{HGV}$ infection is very common in both rural and urban South African populations. The prevalence of HGV viraemia in all clinical groups was $20 \%$ (116 of 580) (tables 2 and 3 ). In keeping with studies in developed countries, ${ }^{2}{ }^{13} \mathrm{HGV}$ RNA was found in persons infected with HBV (26.4\%) and HCV $(30.5 \%)$ (table 3$)$. However, in stark contrast to reports from developed countries, $12.9 \%$ (range $2.9 \%$ to $23.9 \%$ ) of apparently healthy
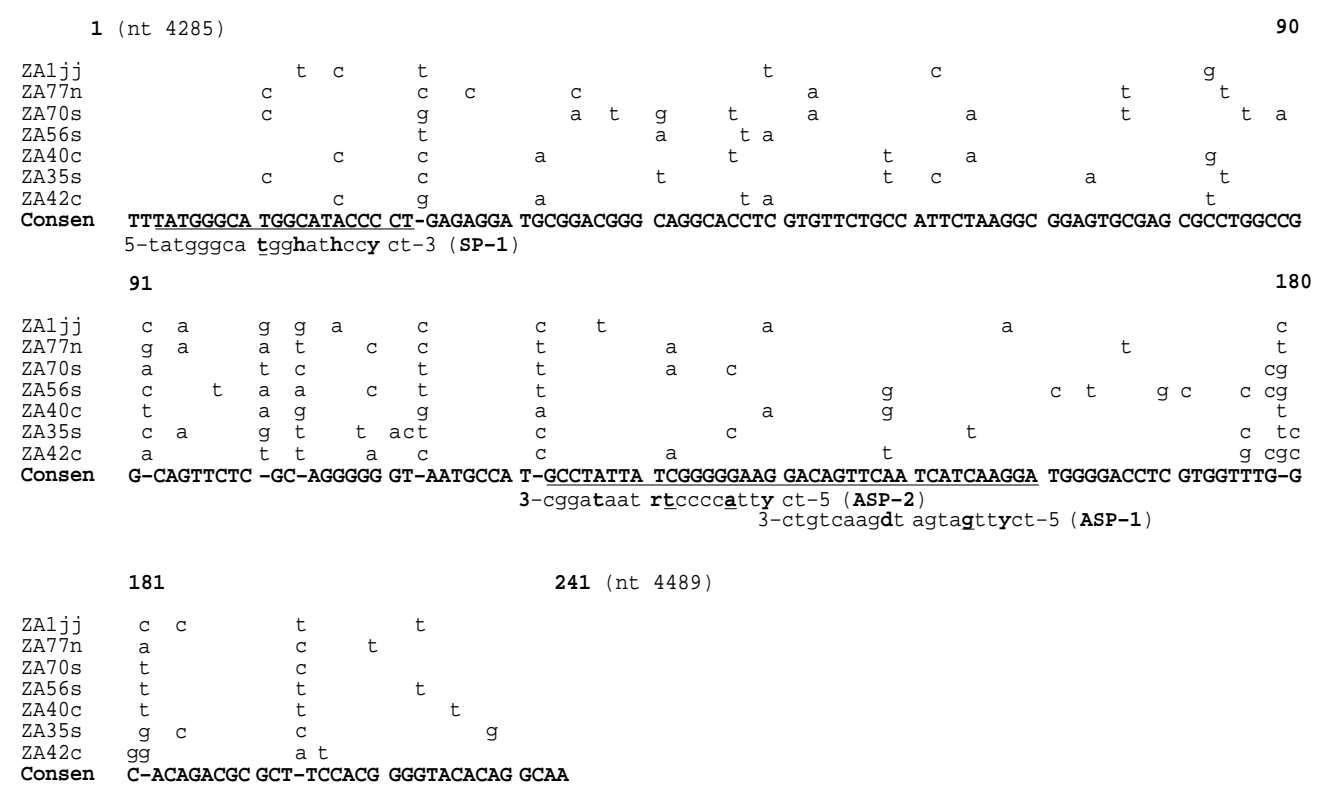

Figure 1 Partial nucleotide sequencing of the putative NS3 helicase region of South African HGV isolates. The isolates sequenced were successfully PCR amplified with both 5'-NCR and NS5a primer pairs from Roche Diagnostics. The sequence is shown as consensus (consen) in bold. Dash (-) refers to unknown consensus nucleotide. For each HGV strain, only the different nucleotides are shown. The sequence shown here corresponds to nucleotides 4285-4489 of HGV strain PNF2161. The positions and primer sequences used for our in-house reverse transcriptase polymerase chain reaction are shown, with nucleotide variations in bold on the corresponding primer sequences. $R, A$ or $G ; Y, C$ or $T ; H, A$ or $C$ or $T ; D$, $A$ or $G$ or $T$; $S P-1$, sense primer 1; $A S P-1$, antisense primer $1 ; A S P-2$, antisense primer 2 . 
South African blacks (who were negative for HBsAg and anti-HCV markers and had normal ALT) were HGV viraemic. This is far higher than the $1-4 \% \mathrm{HGV}$ RNA positivity seen in volunteer blood donors from developed countries ${ }^{24-6}$ or the $0.7-5.7 \%$ observed in some developing parts of Asia such as China $^{27}{ }^{28}$ and Vietnam. ${ }^{29}$ The high prevalence of HGV in South Africa is in accord with other studies conducted in subSaharan Africa. Dawson et al were first to report $\mathrm{HGV}$ viraemia of $14.2 \%$ from a random population in West Africa. ${ }^{4}$ In South Africa, two recently published independent studies have confirmed a high prevalence of $\mathrm{HGV}$ infection. In one study, although no association was found between HGV and hepatocellular carcinoma, $\mathrm{HGV}$ was found in $12.6 \%$ of the hospital based controls in Johannesburg. ${ }^{18}$ The other study showed HGV viraemia in $10.4 \%$ of the rural population residing in the Eastern Cape. ${ }^{19}$

Our data showed that the rate of $\mathrm{HGV}$ infection increases with age. Nine per cent of children below 15 years of age (20 of 223) were $\mathrm{HGV}$ viraemic. The number of positive individuals increased to $28.6 \%$ (42 of 147) for the group between age 16 and 35 years and declined slightly to $24.5 \%$ (37 of 151 ) thereafter (table 3 ). There was a strong association between HGV viraemia and age $(p=0.001)$. The implication is that many individuals in South Africa are exposed to $\mathrm{HGV}$ during childhood. This is supported by the anti-E2 prevalence paralleling the rate of active infection in all age groups (table 4). The ongoing infection in young adults could reflect sexual and blood exposure. In South African children, the route of transmission is mainly horizontal as only three of 104 newborn babies $(2.9 \%)$ tested HGV RNA positive. In contrast to developed countries, a higher prevalence $(9.0 \%)$ of active HGV infection noted in children aged less than 15 years (most of whom are from rural areas) does not support blood transfusion and intravenous drug use as major risk factors for acquisition of $\mathrm{HGV}$ in South Africa in childhood. Along with the small additional association with $\mathrm{HBV}$ and $\mathrm{HCV}$ infection in our population, this implies that HGV occurs commonly and is not necessarily subject to the same risk factors as $\mathrm{HBV}$ or HCV. In fact, previous studies conducted in the Ga-Rankuwa general population and elsewhere in South Africa have shown a low anti$\mathrm{HCV}$ prevalence $(<1 \%),{ }^{30}{ }^{31}$ indicating that although HGV and HCV are both flaviviruses, $\mathrm{HGV}$ infection is substantially more prevalent in this community than HCV infection. It was also evident that transmission of $\mathrm{HGV}$ is independent of HAV and HEV, as there was a frequent detection of active $\mathrm{HGV}$ infection in individuals without serological exposure to hepatitis A-E viruses (table 3). Our data are supported by a German study in which nine of 80 healthy regular blood donors (11.3\%), negative for HIV-1, HIV-2, HBV, and HCV and with normal ALT, were positive for $\mathrm{HGV}$ RNA or anti-E2 protein of $\mathrm{HGV}$, further suggesting that $\mathrm{HGV}$ transmission is not restricted to the same risk factors as HBV, HCV, or HIV, even in developed countries. $^{23}$

Finally, differential sensitivity (probably caused by sequence variation) of PCR primers for South African HGV isolates was observed (table 2). This was in part confirmed by partial sequence analysis of the NS3 helicase of selected South African HGV strains. A few nucleotide changes were seen in the primer binding sites of the sequences of our local strains that may partly explain why some HGV strains were successfully amplified using both the 5'-NCR and NS5a primers from the Roche Diagnostics PCR assay, but not with the NS3 seminested primers used for our in-house RT-PCR (fig 1).

CONCLUSIONS

It is not known why the total burden of HGV infection is so high in some parts of the developing world such as subSaharan Africa, while in other developing countries such as China the prevalence is similar to that observed in Europe or the USA. The chance of chronic infection, expressed as the number of active infections compared with the total burden, is no higher than in other countries. Perhaps arthropod transmission is responsible. As yet, no clear association with disease has been described, and HGV is not obviously linked to hepatitis. The reagents for RT-PCR were kindly provided by Roche Diag-
nostics. The study was supported, in part, by the South African Medical Research Council, Foundation for Research Development, and Ernest Oppenheimer Memorial Trust, South Africa.

1 Simons JN, Leary TP, Dawson GJ, et al. Isolation of novel virus-like sequences associated with human hepatitis. Nature Med 1995;1:564-9.

2 Linnen J, Wages J, Zhang-Keck Z-Y, et al. Molecular cloning and disease association of hepatitis $\mathrm{G}$ virus: a transfusiontransmissible agent. Science 1996;271:505-8.

3 Leary TP, Muerhoff AS, Simons JN, et al. Sequence and genetic organisation of GBV-C: a novel member of the Flaviviridae associated with human non A-E hepatitis. 7 Med Virol 1996;48:60-7.

4 Dawson GJ, Schlauder GG, Pilot-Matias TJ, et al. Prevalence studies of GB virus-C infection using reverse transcriptase-polymerase chain reaction. $\mathcal{F}$ Med Virol 1996; 50:97-103.

5 Schlueter V, Schmolke S, Stark K, et al. Reverse Schlueter V, Schmolke S, Stark $\mathrm{K}$, et al. Reverse
transcription-PCR detection of hepatitis $\mathrm{G}$ virus. $\mathcal{F}$ Clin Microbiol 1996;34:2660-4

6 Masuko K, Mitsui T, Iwano K, et al. Infection with hepatitis $\mathrm{GB}$ virus C in patients on maintenance haemodialysis. $N$ Engl $\mathcal{F}$ Med 1996;334:1485-90.

7 Feucht HH, Zollner B, Polywka S, et al. Vertical transmission of HGV. Lancet 1996;347:615-16.

8 Moaven LD, Tonnakoon PS, Bowden DS, et al. Mother-tobaby transmission of hepatitis $\mathrm{G}$ virus. Med $\mathcal{F}$ Aust 1996;165:84-5.

9 Lin $\mathrm{H}-\mathrm{H}$, Kao J-H, Yeh K-Y, et al. Mother-to-infant transmission of GB virus C/hepatitis $\mathrm{G}$ virus: the role of high titre maternal viraemia and mode of delivery. F Infect Dis 1998; 177:1202-6.

10 Persico T, Thiers V, Triveri R, et al. Detection of hepatitis G/GBV-C viral RNA but not HCV RNA in the different semen fractions of infected patients [abstract]. Hepatology 1996;24:226A.

11 Chen M, Sonnerborg A, Johansson B, et al. Detection of hepatitis $\mathrm{G}$ virus (GB virus $\mathrm{C}$ ) in human saliva. F Clin Microbiol 1997;35:973-5.

12 Selvey LA, Hyland CA, Mison L, et al. Is there evidence for vector transmission of GBV-C? Lancet 1998;351:1104-5.

13 Schleicher S, Chaves RL, Dehmer, et al. Identification of GBV-C hepatitis G RNA in chronic hepatitis C patients. $\mathcal{F}$ Med Virol 1996;50:71-4.

14 Mphahlele MJ, Lau GKK, Carman WF. HGV: the identification, biology and prevalence of an orphan virus. Liver 1998;18:143-55.

15 Madejon A, Fogeda M, Bartolome J, et al. GB virus C RNA in serum, liver, and peripheral blood mononuclear cells from patients with chronic hepatitis B, C and D. Gastroenterology 1997;113:573-8. 
16 Saito S, Tanaka K, Kondo $\mathrm{M}$, et al. Plus- and minusstranded hepatitis G virus RNA in liver tissue and in peripheral blood mononuclear cells. Biochem Biophys Re Commun 1997,237:288-91.

17 Laskus T, Wang L-F, Radkowski M, et al. Hepatitis G virus infection in American patients with cryptogenic cirrhosis: no evidence for liver replication. F Infect Dis 1997;176: $1491-5$

18 Lightfoot K, Skelton M, Kew MC, et al. Does hepatitis GB virus-C infection cause hepatocellular carcinoma in black Africans? Hepatology 1997;26:740-2.

19 Tucker TJ, Louw SJ, Robson SC, et al. High prevalence of GBV-C hepatitis G virus infection in a rural South African population. F Med Virol 1997;53:225-8.

20 Heringlake S, Osterkamp S, Trautwein C, et al. Association between fulminant hepatic failure and a strain of GBV virus C. Lancet 1996;48:1626-9.

21 Yoshiba $M$, Okamoto $H$, Mishiro S. Detection of the GBV-C hepatitis virus genome in serum from patients with fulminant hepatitis of unknown aetiology. Lancet 1995;346: 1131-2.

22 Casteling A, Sim J, Vardas E, et al. Hepatitis GBV-C in South Africa. South African Med $\mathcal{F}$ 1997;87:182-3.

23 Tacke M, Kiyosawa K, Stark K, et al. Detection of antibodies to a putative hepatitis $\mathrm{G}$ virus envelope protein. Lancet 1997;349:318-20.
24 Dille BJ, Srowy TK, Gutierrez RA, et al. An ELISA for detection of antibodies to $\mathrm{E} 2$ protein of GB virus C. F Infect Dis 1997;175: 485-61.

25 Gutierrez RA, Dawson GT, Knigge MF, et al. Seroprevalence of $\mathrm{GB}$ virus $\mathrm{C}$ and persistence of RNA and antibody. 7 Med Virol 1997;53:167-73.

26 Erker JC, Simons JN, Muerhoff AS, et al. Nucleotide sequence of a $\mathrm{GB}$ virus $\mathrm{C}$ isolate from a patient with non A-E hepatitis. I Gen Virol 1996;77:2713-20.

27 Wang Y, Chen H-S, Fan M-H, et al. Infection with GB virus $\mathrm{C}$ and hepatitis $\mathrm{C}$ virus in haemodialysis and blood donors in Beijing. f Med Virol 1997;52:26-30.

28 Wang H-L, Jin D-Y. Prevalence and genotype of hepatitis G virus in Chinese professional blood donors and hepatitis patients. F Infect Dis 1997;175:1229-33.

29 Brown KE, Wong S, Buu M, et al. High prevalence of GB virus $\mathrm{C} /$ hepatitis $\mathrm{G}$ virus in healthy persons in Ho Chi Minh City, Vietnam. F Infect Dis 1997;175:450-3.

30 Basetse HR, Peenze I, Aspinall S. Hepatitis C virus antibodies in the black population of Ga-Rankuwa. Medical Technology South Africa 1993;6:88-9.

31 Soni PN, Tait DR, Kenoyer DG, et al. Hepatitis C virus antibodies among risk groups in a South African area endemic for hepatitis B virus. F Med Virol 1993;40:65-8. 